\title{
Balıklardan İzole Edilen Bazı Bakteriyel Patojenlere Karşı Tannik Asitin Antibakteriyal Etkisinin Belirlenmesi ${ }^{[*]}$
}

\author{
Fikri BALTA ${ }^{1 *} \quad$ Neșe TEKIN ${ }^{2}$ \\ ${ }^{1}$ Recep Tayyip Erdoğan Üniversitesi, Su Ürünleri Fakültesi, Hastalıklar Anabilim Dall, 53100, Rize, Türkiye \\ ${ }^{2}$ Recep Tayyip Erdoğan Üniversitesi, Lisansüstü Eğitim Enstitüsü, Su Ürünleri Anabilim Dal,, Rize, Türkiye
}

Atıf yapmak için: Balta, F. \& Tekin, N. (2021). Balıklardan izole edilen bazı bakteriyel patojenlere karşı tannik asitin antibakteriyal etkisinin belirlenmesi. Anadolu Çev. ve Hay. Dergisi, 6(4), 532-539.

How to cite: Balta, F. \& Tekin, N. (2021). Determination of antibacterial effect of tannic acid against some bacterial pathogens 1solated from fish. J. Anatolian Env. and Anim. Sciences, 6(4), 532-539.

iD: https://orcid.org/0000-0002-1823-5823 (iD): https://orcid.org/0000-0001-9734-9871
Öz: Bu çalışmada, bitkilerden doğal ekstraksiyon ișlemiyle elde edilen ve su ürünleri yetiştiriciliğinde tatlandırıcı yem katkı maddesi olarak kullanılan Silvafeed TSP'nin (tannik asit) Aeromonas hydrophila, Pseudomonas fluorescens, Yersinia ruckeri, Vibrio anguillarum ve Escherichia coli'ye (ATCC 25922) karş1 antimikrobiyal etkinliği agar well difüzyon ve minimal inhibisyon konsantrasyon testi (MIK) ile araştırıldı. Agar well difüzyon testinde, A. hydrophila, E. coli ve $Y$. ruckeri izolatlarının $12,5 \mu \mathrm{g} / \mathrm{ml}$ 'nin üzerindeki konsantrasyonlara duyarlı iken, $P$. fluorescens ve $V$. anguillarum izolatlarının $6,25 \mu \mathrm{g} / \mathrm{ml}$ 'nin üzerindeki tannik asit konsantrasyonlarına hassas olduğu belirlendi. Disk difuzyon testinde $P$. fluorescens' in gentamisin ve doksisiklin hariç çalışmada kullanılan diğer antimikrobiyel ajanlara karşı dirençli olduğu, A. hydrophila, E. coli, V. anguillarum ve $Y$. ruckeri'nin ise ampisilin hariç çalışmada kullanılan diğer antibiyotiklere karşı hassas olduğu tespit edildi. Bu çalışmada, P. fluorescens izolatının florfenikol (FFC)'ün $200 \mu \mathrm{g} / \mathrm{ml}$ hariç bütün konsantrasyonları ve $E$. coli izolatının sadece FFC'nin $3,125 \mu \mathrm{g} / \mathrm{ml}$ konsantrasyonuna dirençli olduğu tespit eddildi. Fakat, doksisiklinin beş bakteri izolatına karşı duyarlı olduğu belirlendi. Tannik asitin 6,25 $\mu \mathrm{g} / \mathrm{ml}$ konsantrasyonuna $P$. fluorescens ve $V$. anguillarum dirençli iken, $12.5 \mu \mathrm{g} / \mathrm{ml}$ konsantrasyonu ise $E$. coli, A. hydrophila ve $Y$. ruckeri'nin dirençli olduğu belirlendi. Tannik asitin MİK değeri; E. coli için 187,5 $\mu \mathrm{g} / \mathrm{ml}$, A. hydrophila için $250 \mu \mathrm{g} / \mathrm{ml}$, P. fluorescens için $31,25 \mu \mathrm{g} / \mathrm{ml}$, V. anguillarum $375 \mu \mathrm{g} / \mathrm{ml}$ ve $Y$. ruckeri için $125 \mu \mathrm{g} / \mathrm{ml}$ olarak belirlendi. $P$. fluorescens izolatı için florfenikolün MİK değerleri belirlenemezken; $E$. coli, A. hydrophila, V. anguillarum ve $Y$. ruckeri için sırasıyla, $25 \mu \mathrm{g} / \mathrm{ml}, 12,5 \mu \mathrm{g} / \mathrm{ml}, 12,5 \mu \mathrm{g} / \mathrm{ml}$ ve $50 \mu \mathrm{g} / \mathrm{ml}$ olduğu belirlendi.

Anahtar kelimeler: Akuakültür, antimikrobiyal hassasiyet, Mİ, tannik asit, tedavi.

\section{Determination of Antibacterial Effect of Tannic Acid Against Some Bacterial Pathogens Isolated from Fish}

Fikri BALTA

Recep Tayyip Erdoğan Üniversitesi, Su

Urünleri Fakültesi, Hastalıklar Anabilim Dalı,

Fener Mah. 53100/Rize, Türkiye

凶: fikri.balta@erdogan.edu.tr
Abstract: In this study, the antimicrobial activity was investigated Silvafeed TSP (tannic acid) obtained by natural extraction from plants and used as a flavoring feed additive in aquaculture, against Aeromonas hydrophila, Pseudomonas fluorescens, Yersinia ruckeri, Vibrio anguillarum and Escherichia coli (ATCC 25922). For this purpose, agar well diffusion and minimal inhibition concentration (MIC) tests were used. In the agar well diffusion test, it was determined that A. hydrophila, E. coli and Y. ruckeri isolates were sensitive to concentrations above $12,5 \mu \mathrm{g} / \mathrm{ml}$, while $P$. fluorescens and $V$. anguillarum isolates were sensitive to tannic acid concentrations above $6,25 \mu \mathrm{g} / \mathrm{ml}$. In the disc diffusion test, it was determined that $P$. fluorescens was resistant to other antimicrobial agents used in the study except gentamicin and doxycycline, and $A$. hydrophila, E. coli, V. anguillarum and Y. ruckeri were sensitive to other antibiotics used in the study except ampicillin. In this study, it was determined that the $P$. fluorescens isolate was resistant to all concentrations of florfenicol (FFC) except $200 \mu \mathrm{g} / \mathrm{ml}$ and the $E$. coli isolate was resistant only to the $3.125 \mu \mathrm{g} / \mathrm{ml}$ concentration of FFC. However, doxycycline concentrations were determined to be sensitive to five bacterial isolates. It was determined that $P$. fluorescens and $V$. anguillarum were resistant to the $6.25 \mu \mathrm{g} / \mathrm{ml}$ concentration, while E. coli, A. hydrophila and Y. ruckeri were resistant to the $12.5 \mu \mathrm{g} / \mathrm{ml}$ concentration of tannic acid. The MIC values of tannic acid for E. coli, A. hydrophila, P. fluorescens, V. anguillarum and $Y$. ruckeri were determined as $187,5 \mu \mathrm{g} / \mathrm{ml}, 250 \mu \mathrm{g} / \mathrm{ml}, 31.25 \mu \mathrm{g} / \mathrm{ml}, 375 \mu \mathrm{g} / \mathrm{ml}$ and $125 \mu \mathrm{g} / \mathrm{ml}$, respectively. While MIC values of florfenicol could not be determined for $P$. fluorescens isolate; It was determined as 25 $\mu \mathrm{g} / \mathrm{ml}, 12.5 \mu \mathrm{g} / \mathrm{ml}, 12.5 \mu \mathrm{g} / \mathrm{ml}$ and $50 \mu \mathrm{g} / \mathrm{ml}$ for E. coli, A. hydrophila, P. fluorescens, V. anguillarum and $Y$. ruckeri, respectively.

Keywords: Antimicrobial susceptibility, aquaculture, MIC, tannic acid, treatment. 


\section{GíRiş}

İntensif gökkuşağı alabalık yetiştiriciliğinde artan tüketici taleplerini karşılamak için her geçen gün üretimdeki artışa bağlı olarak balık hastalık sorunları ile sıklıkla karşılaşılmaktadır. Gökkuşağı alabalık yetiştiriciliğinde havuzlarda aşırı stok yoğunluğu bakteriyel balık hastalıklarının ortaya çıkmasına sebep olmaktadır. Bu hastalıkların erken teşhisinin ve tedavisinin yapılmaması durumu, toplu ölümler görülebilmekte ve bu nedenle işletmelerde ekonomik yönden büyük kayıpların ortaya çıkmasına sebep olabilmektedir. $\mathrm{Bu}$ durum akuakültürde sürdürülebilir üretimi önemli ölçüde etkilemektedir. Balıklardan görülen bakteriyel hastalıkların tedavisi genellikle, antibiyogram test sonuçlarına göre yapılmaktadır. Test sonucuna göre en etkili ve ucuz olan antibiyotik tercih edilmektedir. Son yıllarda; akuakültürde kullanılan antibiyotiklere karşı kazanılan direnci ve insan sağlığı açısından antibiyotik kalıntı problemlerini ortadan kaldırmak amacıyla organik balık yetiştiriciliğinde alternatif olarak kullanılabilecek doğal bitkisel kökenli (kestane ağacı) bir yem katkı maddesi olan silvafeed (tannik astin) kullanılması düşünülmüştür. Silvafeed ekşimsi tatta, kahverengi renkte, toz formunda, minimum $\% 75$ polifenol içeriğine sahip olan ve maksimum $\% 8$ rutubet stoklanmış bir tanen (tannik asit) bileşiğidir (http, 2021).

Tanenlerin (tannik asitler), antimikrobiyal, antienflamatuar, antiviral, antioksidan ve antiparazitik aktiviteler gibi önemli biyolojik özelliklere sahip suda çözünebilen polifenolik bileşikler grubu kimyasal maddeler olduğu rapor edilmiştir (Pérez-Fonseca vd., 2016). Tanenlerin çeşitli bitkilerin kabukları, meyveleri, yaprakları ve kökleri gibi farklı kısımlarında yaygın olarak bulundukları bildirilmiştir (EL-Hefny vd., 2017). Tanenlerin hidrolize olabilen ve kondanse (yoğunlaştırılmış) olabilen iki farklı tipleri bulunmaktadır. Tanenlerin başlica görevlerinin proteinleri ve diğer makromolekülleri bağlama ve çökeltme olduğu bildirilmiştir (Brooker vd., 1994). Mide-bağırsak sistemi bakterilerinin tanenleri ve tanik asit-protein komplekslerini parçalayabildikleri veya tolere edebildikleri rapor edilmiştir. Ayrıca, hidrolize olabilen tanenlerin (tanik asit), hayvanlar ve rumen mikroorganizmaları için toksik etki meydana getirdiği bildirilmiştir (Brooker vd., 1994; Salem vd., 2010; Bae vd., 1993). Tanenlerin inhibitör etkisinin bakterilerin hücre duvarında fonksiyon bozukluğu meydana getirmesine, enzim aktivitesini azaltılmasına, metal iyonları (demirle şelasyon oluşturarak) ve minerallerin yoksunluğuna bağlı olarak gösterdiği bildirilmiştir (Goel vd., 2005; Cipriano-Salazara vd., 2018).
Bu çalışmada, Karadeniz bölgesindeki gökkuşağ alabalığı üretim çiftliklerinde hastalık epizootilerinde en çok rastlanılan ve izole edilen Gram negatif bakterilerden olan A. hydrophila, $P$. fluorescens, $Y$. ruckeri ve $V$. anguillarum izolatlarına karşı silvafeed'in (tannik asit) antimikrobiyal aktivitesinin belirlenmesi amaçlanmıştır.

\section{MATERIAL AND METHOD}

Silvafeed TSP (Tannik Asit), Doksisiklin ve Florfenikol Stok Solüsyonlarının Hazırlanması: $\mathrm{Bu}$ çalışmada kullanılan Silvafeed TSP, Profeed Gıda ve Kim. Mad. San. Tic. Ltd. Şti. şirketinden ücretsiz olarak temin edildi. Silvafeed TSP, bitkilerden doğal ekstraksiyon işlemleri kullanılarak elde edilen suda çözünür toz şeklindeki ticari bir üründür. Silvafeed'in antimikrobiyal etkinliğinin belirlenmesi amaciyla öncelikle, 0,2 ve $0,3 \mathrm{gr}$ Silvafeed $100 \mathrm{ml}$ saf suda ayrı ayrı çözdürülerek stok solüsyonları hazırlandı. Hazırlanmış olan bu stok solüsyonlarından $20 \mathrm{ml}$ cam şişeler içerisinde 2 katlı ve 10 katlı dilüsyonları hazırlanarak çalışmada test edilecek konsantrasyonlar hazırlandı. Doksisiklin (Medox \%50 Toz-Medicated) ve florfenikol'ün (Florfish \%50 TozMedicated)her birinden 0,4'er gr tartıld. Balon jojede (100 ml) \%2'lik $0,1 \mathrm{M} \mathrm{HCl}$ içeren methanol çözeltisinde manyetik bir bar yardımıyla manyetik karıştırıcıda homojen hale getirildi. Hazırlanan stok solüsyonları steril 0,45 $\mu$ m'lik membran flitre (Merck-Millipore) yardımı ile steril edildi. Tannik asit'in (0,2 gr'dan hazırlanmış) dilüsyonları ve konsantrasyonları Tablo 1'de verildi.

Tablo 1. Tannik asitin iki katlı seri dilüsyonlarının konsantrasyonları.

Table 1. Concentrations of two-fold serial dilutions of tannic acid.

\begin{tabular}{|c|c|c|}
\hline Tüpler & Tannik asitin iki katlı seri dilüsyonları & Konsantrasyonu \\
\hline 1. & $1 \mathrm{ml} \rightarrow 2 \mathrm{mg}(=2000 \mu \mathrm{g})$ & $2000 \mu \mathrm{g}$ TA \\
\hline 2. & $1 \mathrm{ml} 2000 \mu \mathrm{g} \mathrm{TA}+1 \mathrm{ml}$ steril su & $1000 \mu \mathrm{g}$ TA \\
\hline 3. & $1 \mathrm{ml} 1000 \mu \mathrm{g} \mathrm{TA}+1 \mathrm{ml}$ steril su & $500 \mu \mathrm{g}$ TA \\
\hline 4. & $1 \mathrm{ml} 500 \mu \mathrm{g} \mathrm{TA}+1 \mathrm{ml}$ steril su & $250 \mu \mathrm{g}$ TA \\
\hline 5. & $1 \mathrm{ml} 250 \mu \mathrm{g} \mathrm{TA}+1 \mathrm{ml}$ steril su & $125 \mu \mathrm{g}$ TA \\
\hline 6. & $1 \mathrm{ml} 125 \mu \mathrm{g} \mathrm{TA}+1 \mathrm{ml}$ steril su & $62,5 \mu \mathrm{g}$ TA \\
\hline 7. & $1 \mathrm{ml} 62,5 \mu \mathrm{g} \mathrm{TA}+1 \mathrm{ml}$ steril su & $31,25 \mu \mathrm{g}$ TA \\
\hline 8. & $1 \mathrm{ml} 31,25 \mu \mathrm{g} \mathrm{TA}+1 \mathrm{ml}$ steril su & $15,625 \mu \mathrm{g} \mathrm{TA}$ \\
\hline 9. & 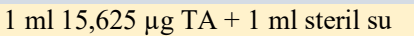 & $7,8125 \mu \mathrm{g} \mathrm{TA}$ \\
\hline 10 & 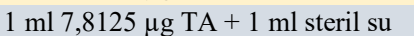 & $3,90625 \mu \mathrm{g}$ TA \\
\hline 11. & $0,1 \mathrm{M} \mathrm{HCl}$ içeren methanol & Kontrol \\
\hline
\end{tabular}

Hazırlanan stok 0,4 gr \%50'lik florfenikol ve 0,4 gr \%50’lik doksisiklin antibiyotik çözeltileri \%50'lik olduğu için $1 \mathrm{ml}$ 'sinde $2 \mathrm{mg}(=2000 \mu \mathrm{g})$ etken madde bulunmaktadır. Florfenikol ve doksisiklinin iki katlı seri dilüsyonlarının konsantrasyonları aşağıdaki gibi hesaplandı ve Tablo 2'de verildi. 
Tablo 2. Florfenikol ve doksisiklinin iki katlı seri dilüsyonlarının konsantrasyonlar1.

Table 2. Concentrations of serial two-fold dilutions of florfenicol and doxycycline.

\begin{tabular}{lll}
\hline Tüpler & DO ve FFC'ün iki katlı seri dilüsyonları & Konsantrasyonu \\
\hline 1. & $1 \mathrm{ml} \rightarrow 1 \mathrm{mg}(=2000 \mu \mathrm{g})$ & $2000 \mu \mathrm{g}$ \\
2. & $1 \mathrm{ml} 2000 \mu \mathrm{g}+1 \mathrm{ml}$ steril su & $1000 \mu \mathrm{g}$ \\
3. & $1 \mathrm{ml} 100 \mu \mathrm{g}+1 \mathrm{ml}$ steril su & $500 \mu \mathrm{g}$ \\
4. & $1 \mathrm{ml} 500 \mu \mathrm{g}+1 \mathrm{ml}$ steril su & $250 \mu \mathrm{g}$ \\
5. & $1 \mathrm{ml} 250 \mu \mathrm{g}+1 \mathrm{ml}$ steril su & $125 \mu \mathrm{g}$ \\
6. & $1 \mathrm{ml} 125 \mu \mathrm{g}+1 \mathrm{ml} \mathrm{steril} \mathrm{su}$ & $62,5 \mu \mathrm{g}$ \\
7. & $1 \mathrm{ml} 62,5 \mu \mathrm{g}+1 \mathrm{ml}$ steril su & $31,25 \mu \mathrm{g}$ \\
8. & $1 \mathrm{ml} 31,25 \mu \mathrm{g}+1 \mathrm{ml}$ steril su & $15,625 \mu \mathrm{g}$ \\
9. & $1 \mathrm{ml} 15,625 \mu \mathrm{g}+1 \mathrm{ml}$ steril su & $7,8125 \mu \mathrm{g}$ \\
10. & $1 \mathrm{ml} 7,8125 \mu \mathrm{g}+1 \mathrm{ml}$ steril su & 3,90625 \\
11. & $0,1 \mathrm{M} \mathrm{HCl} \mathrm{içeren} \mathrm{methanol} \mathrm{+} 1 \mathrm{ml}$ steril su & Kontrol \\
\hline
\end{tabular}

Çalışmada Kullanılan Mikroorganizmalar: Çalışmada Doğu Karadeniz Bölgesi'ndeki gökkuşağı alabalığı çiftliklerinden daha önceki çalışmalarda izole ve identifiye edilmiş olan A. hydrophila, P. fluorescens (P73), $V$. anguillarum (V976) ve Y. ruckeri izolatları kullanıld1 (Balta vd., 2010; Balta, 2016; Balta \& Dengiz Balta, 2016; Balta \& Dengiz Balta, 2017; Kacar \& Balta, 2017, Balta, 2020). Tüm izolatlar kullanılıncaya kadar $-80^{\circ} \mathrm{C}$ 'de $\% 1,5$ gliserol içeren besi yerinde muhafaza edildi. Ayrıca, Silvafeed'in etkinliğinin belirlenmesi amaciyla $E$. coli (ATCC 25922) suşu kullanıldı. Çalışmada test edilen bakteri izolatları ve kökenleri Tablo 3 'de verildi.

Tablo 3. Bakteri türleri ve kökenleri.

Table 3. Bacteria species and origins.

\begin{tabular}{lll}
\hline No & Bakteri Türü & Köken \\
\hline 1 & E. coli & ATCC 25922 \\
2 & A. hydrophila & Alabalık-Rize \\
3 & P. fluorescens & Alabalık-Rize \\
4 & V. anguillarum & Alabalık-Rize \\
5 & Y. ruckeri & Alabalık-Trabzon \\
\hline
\end{tabular}

Agar Well Difüzyon Testi: Silvafeed TSP, doksosillin ve florfenikol'ün antimikrobiyal duyarlılığının belirlenmesinde Arret vd., 1971'de kullanıldığı metot modifiye edilerek kullanıldı (Balta, 1999; Balta \& Çağırgan, 2007; Balta \& Çağırgan, 2010). Bu amaçla Antibiyotik Medium No: 2 yerine Mueller Hinton Agar (MHA-Merck) kullanıldı. E. coli, A. hydrophila, P. fluorescens ve $Y$. ruckeri mikroganizmaları için normal MHA ve $V$. anguillarum için ise tuzlu MHA kullanıldı. Hazırlanan besi yerleri üzerine steril porselen boncuklar kullanılarak kuyucuklar açıldı. Daha sonra mikroorganizmaların bir gecelik taze kültürlerinden fizyolojik tuzlu su (\%0,9 $\mathrm{NaCl})$ içerisine McFarland 0,5'e göre süspansiyonları hazırlandı. Hazırlanmış olan süspansiyonlardan 1 'er $\mathrm{ml}$ alınarak besiyerlerine yayma tarzında ekimleri yapıldı. Daha önceden hazırlanan stok tannik asit, doksisiklin ve florfenikol solüsyonunlarından hazırlanan farklı konsantrasyondaki dilüsyonların her birinden otomatik pipet yardımı ile $100 \mu \mathrm{l}$ alınarak 3'er paralel olmak üzere kuyucuklara ilave edildi. Kontrol olarak 1 kısım methanol (\%2'lik 0,1M HCl içeren) +1 kısım steril saf su içeren dilüsyondan 3 paralel olmak üzere
$100 \mu \mathrm{l}$ miktarında kuyucuklara ilave edildi. Farklı konsantrasyonlardaki tannik asit, doksisiklin ve florfenikol ilave edilmiş 6 kuyucuklu besiyerleri $25^{\circ} \mathrm{C}$ 'de 18 saat inkübasyona bırakıldı. Bu inkubasyonun sonrasında her bir kuyucuğun etrafinda oluşan bakterinin üremediği zon çapları dijital kompas yardımı ile ölçülerek değerlendirildi.

Disk Difüzyon Testi: Mikroorganizmaların antibiyotik duyarlılıklarının belirlenmesinde Kirby-Bauer disk difüzyon (1959-1960) yöntemi kullanıldı. Bu amaçla çalışmada kullanılan her bir bakteri izolatın ve standart suşun bir gecelik subkültürleri FTS içerisine alınarak yoğunlukları Mc Farland No 0,5'e göre ayarlandı. Daha sonra hazırlanmış olan bakteriyel süspansiyonlardan $0.1 \mathrm{ml}$ alınarak MHA'ya ekildi. Ekim sonrası petriler $30 \mathrm{dk}$ oda sıcaklığında bırakıldı ve bu süre sonunda agar yüzeyine antibiyotik diskleri yerleştirildi. Çalışmada ampisilin (10 $\mu \mathrm{g})$, gentamisin $(10 \mu \mathrm{g})$, doksisiklin $(30 \mu \mathrm{g})$, enrofloksasin $(5 \mu \mathrm{g})$, oksitetrasiklin $(30 \mu \mathrm{g})$ sulfamethoksazol $(100 \mu \mathrm{g})$ ve trimetoprim/sulfamethakzol $(1.25 / 23.75 \mu \mathrm{g})$ olmak üzere 8 farklı antibiyotik diski (Bioanalyse) kullanıldı. Antibiyotik diskleri yerleştirilen petriler $25^{\circ} \mathrm{C}$ 'de 18 saat inkubasyona birakıld1. İnkubasyon sonrası antibiyotik diskleri etrafında oluşan bakerinin üremediği inhibisyon zon çapları dijital kumpas yardımı ile ölçüldü (NCCLS, 1993).

Minimal İnhibe Edici Konsantrasyonun (Mí)

Belirlemesi: Testte kullanılacak tannik asit ve florfenikol'ün stok çözeltisi hazırlanırken 100 'er $\mathrm{ml}$ \%2'lik HCl (Merck) içeren methanol solüsyonu kullanıldı. Hassas terazide 0,2 ve 0,3 gr tannik asit ve 0,4 gr florfenikol tartılarak $100 \mathrm{ml}$ 'lik balonjojede \%2'lik 0,1M $\mathrm{HCl}$ içeren methanol çözeltisinde çözdürüldü. Stok solüsyonlar steril $20 \mathrm{ml}$ şişelere 5'er ml olarak bölündü. $E$. coli, A. hydrophila, $P$. fluorescens ve $Y$. ruckeri TSB'de ve $V$. anguillarum $\% 1,5$ tuz ilave edilmiş TSB' de $25^{\circ} \mathrm{C}$ 'de 18 saat inkube edilerek üretildi. Üretilen kültürden kontrol grubu hariç her bir tüpe $10 \mu \mathrm{l}\left(10^{8} \mathrm{cfu} / \mathrm{ml}\right)$ eklendi. Tüpler $25^{\circ} \mathrm{C}$ 'de 24 saat inkübe edildi. Tannik asit ve florfenikol her bir konsantrasyonu için iki tüp paralel olarak çalışıldı. Bakterilerin üremediği tüplerdeki kimyasal maddenin en düşük konsantrasyon MIK değeri olarak kabul edildi (Beşe, 1989).

Önceden steril edilen tannik asit stok solüsyonu Mueller Hinton Broth'da (MHB) iki katlı seri dilüsyonları gerçekleştirildi. Mueller Hinton Broth'da tannik asit MIKK değerlerini belirlemek için hazırlanan iki katlı seri dilüsyonların farklı konsantrasyonları Tablo 4'de verildi.

Florfenikol $1 \mathrm{ml}$ 'sinde $2000 \mu \mathrm{g}$ olduğu için ilk önce 10 katlı dilüsyonu yapılarak içindeki etken madde miktarı $200 \mu \mathrm{g}$ 'a düşürüldü. Mueller Hinton Broth'da florfenikolün MİK değerlerini belirlemek için hazırlanan iki katlı seri dilüsyonların farklı konsantrasyonları Tablo 5 'de verildi. 
Tablo 4. MIKK değerleri için tannik asitin farklı konsantrasyonları.

Table 4. Different concentrations of tannic acid for MIC values.

\begin{tabular}{lll}
\hline Tüpler & Tannik asit iki katlı seri dilüsyonları & Konsantrasyonu \\
\hline 1. & $1 \mathrm{ml} \mathrm{MHB}+1 \mathrm{ml}(3000 \mu \mathrm{TA})$ & $1500 \mu \mathrm{g}$ \\
2. & $1 \mathrm{ml} \mathrm{MHB}+1 \mathrm{ml}(2000 \mu \mathrm{g} \mathrm{TA})$ & $1000 \mu \mathrm{g}$ \\
3. & $1 \mathrm{ml} \mathrm{MHB}+1 \mathrm{ml}(1500 \mu \mathrm{TA})$ & $750 \mu \mathrm{g}$ \\
4. & $1 \mathrm{ml} \mathrm{MHB}+1 \mathrm{ml}(1000 \mu \mathrm{g} \mathrm{TA})$ & $500 \mu \mathrm{g}$ \\
5. & $1 \mathrm{ml} \mathrm{MHB}+1 \mathrm{ml}(750 \mu \mathrm{g} \mathrm{TA})$ & $375 \mu \mathrm{g}$ \\
6. & $1 \mathrm{ml} \mathrm{MHB}+1 \mathrm{ml}(500 \mu \mathrm{g} \mathrm{TA})$ & $250 \mu \mathrm{g}$ \\
7. & $1 \mathrm{ml} \mathrm{MHB}+1 \mathrm{ml}(375 \mu \mathrm{g} \mathrm{TA})$ & $187,5 \mu \mathrm{g}$ \\
8. & $1 \mathrm{ml} \mathrm{MHB}+1 \mathrm{ml}(250 \mu \mathrm{g} \mathrm{TA})$ & $125 \mu \mathrm{g}$ \\
9. & $1 \mathrm{ml} \mathrm{MHB}+1 \mathrm{ml}(187,5 \mu \mathrm{g} \mathrm{TA})$ & $93,75 \mu \mathrm{g}$ \\
10. & $1 \mathrm{ml} \mathrm{MHB}+1 \mathrm{ml}(125 \mu \mathrm{g} \mathrm{TA})$ & $62,5 \mu \mathrm{g}$ \\
11. & $1 \mathrm{ml} \mathrm{MHB}+1 \mathrm{ml}(62,5 \mu \mathrm{g} \mathrm{TA})$ & $31,25 \mu \mathrm{g}$ \\
12. & $1 \mathrm{ml} \mathrm{MHB}+1 \mathrm{ml}(46,875 \mu \mathrm{g} \mathrm{TA})$ & $23,44 \mu \mathrm{g}$ \\
13. & $1 \mathrm{ml} \mathrm{MHB}+1 \mathrm{ml}(31,25 \mu \mathrm{g} \mathrm{TA})$ & $15,625 \mu \mathrm{g}$ \\
14. & $1 \mathrm{ml} \mathrm{MHB}+\% 2 \mathrm{HCl}$ içeren methanol & Kontrol \\
\hline
\end{tabular}

Tablo 5. MIK değerleri için florfenikolün farklı konsantrasyonları.

Table 5. Different concentrations of florfenicol for MIC values.

\begin{tabular}{lll}
\hline Tüpler & Florfenikolün iki katl seri dilüsyonları & Konsantrasyon \\
\hline 1. & $1 \mathrm{ml} \mathrm{MHB}+1 \mathrm{ml}(200 \mu \mathrm{g}$ FFC $)$ & $100 \mu \mathrm{g}$ \\
2. & $1 \mathrm{ml} \mathrm{MHB}+1 \mathrm{ml}(100 \mu \mathrm{g}$ FFC $)$ & $50 \mu \mathrm{g}$ \\
3. & $1 \mathrm{ml} \mathrm{MHB}+1 \mathrm{ml}(50 \mu \mathrm{g}$ FFC $)$ & $25 \mu \mathrm{g}$ \\
4. & $1 \mathrm{ml} \mathrm{MHB}+1 \mathrm{ml}(25 \mu \mathrm{g}$ FFC $)$ & $12,5 \mu \mathrm{g}$ \\
5. & $1 \mathrm{ml} \mathrm{MHB}+1 \mathrm{ml}(12,5 \mu \mathrm{g} \mathrm{FFC})$ & $6,25 \mu \mathrm{g}$ \\
6. & $1 \mathrm{ml} \mathrm{MHB}+1 \mathrm{ml}(6,25 \mu \mathrm{g} \mathrm{FFC})$ & $3,125 \mu \mathrm{g}$ \\
7. & $1 \mathrm{ml} \mathrm{MHB}+1 \mathrm{ml}(3,125 \mu \mathrm{g}$ FFC $)$ & $1,5625 \mu \mathrm{g}$ \\
8 & $1 \mathrm{ml} \mathrm{MHB}+1 \mathrm{ml}(1,5625 \mu \mathrm{g}$ FFC $)$ & $0,78125 \mu \mathrm{g}$ \\
9. & $1 \mathrm{ml} \mathrm{MHB}+1 \mathrm{ml}(0,78125 \mu \mathrm{g}$ FFC $)$ & $0,390625 \mu \mathrm{g}$ \\
10. & $1 \mathrm{ml} \mathrm{MHB}+1 \mathrm{ml} \% 2^{\prime}$ lik HCl methanol & Kontrol \\
\hline
\end{tabular}

\section{BULGULAR}

Çalışmada dört balık patojeni ve bir standart suşun, silvafeed TSPve sekiz faklı antibiyotiğe karşı hassasiyeti belirlendi. Ayrıca, beş bakterinin tannik asit ve forfenikol karşı MİK değerleri tespit edildi. Agar well difüzyon testinde doksisiklin'in tüm konsantrasyonlarının test mikroorganizmalarına karşı duyarlı bulunması nedeni ile doksisiklin'in MIKK testi yapılmad.

Agar Well Difüzyon Testi: Tannik asitin farklı konsantrasyonlardaki dilüsyonlarının test mikroorganizmalarına karşı antimikrobiyal etkinliği Mueller Hinton Agarda açılan kuyucukların etrafinda oluşan zon çaplarının dijital kompas yardımı ile ölçülmesi ile gerçekleştirildi. Tannik asitin $25 \mu \mathrm{g} / \mathrm{ml}$ ve üzerindeki konsantrasyonlarının E. coli, A. hydrophila ve $Y$. ruckeri izolatlarına karşı duyarlı olduğu tespit edildi. $P$. fluorescens ve $V$. anguillarum'un ise tannik asitin 12,5 $\mu \mathrm{g} / \mathrm{ml}$ ve üzerindeki konsantrasyonlarına karşı duyarlı olduğu tespit edildi (Tablo 6).

Agar well difüzyon testi ile $P$. fluorescens izolatının florfenikolün $200 \mu \mathrm{g} / \mathrm{ml}$ hariç bütün konsantrasyonlarına ve E. coli ATCC 25922 suşunun sadece florfenikol'ün $3,125 \mu \mathrm{g} / \mathrm{ml}$ konsantrasyonuna dirençli olduğu tespit edildi. Diğer bakteri türlerinin hepsinin florfenikol'ün farklı konsantrasyonlarındaki dilüsyonlarına karşı hassas olduğu tespit edildi (Tablo 6). Agar well difüzyon testi ile doksisiklin'in tüm konsantrasyonlarına karşı test mikroorganizmalarının hassas olduğu saptandı (Tablo 6).
Tablo 6. Agar well difüzyon testi ile test mikroorganizmalarına karşı tannik asit, florfenikol ve doksisiklinin etkinliklerinin karşılaştırılması.

Table 6. Comparison of the efficacy of tannic acid, florfenicol and doxycycline against test microorganisms by agar well diffusion test.

\begin{tabular}{|c|c|c|c|c|c|c|}
\hline \multirow{2}{*}{ Kimyasallar } & \multirow{2}{*}{ Konsantrasyon } & \multicolumn{5}{|c|}{ Bakteri izolatları } \\
\hline & & E. coli & A. hydrophila & $P-73$ & $\begin{array}{l}-976 \\
-976\end{array}$ & Y. ruckeri \\
\hline TA & $200 \mu \mathrm{g}$ & $\mathrm{H}$ & $\mathrm{H}$ & $\mathrm{H}$ & $\mathrm{H}$ & $\mathrm{H}$ \\
\hline FFC & $200 \mu \mathrm{g}$ & H & $\mathrm{H}$ & $\mathrm{H}$ & $\mathrm{H}$ & $\mathrm{H}$ \\
\hline DO & $200 \mu \mathrm{g}$ & $\mathrm{H}$ & $\mathrm{H}$ & $\mathrm{H}$ & $\mathrm{H}$ & $\mathrm{H}$ \\
\hline TA & $100 \mu \mathrm{g}$ & $\mathrm{H}$ & $\mathrm{H}$ & $\mathrm{H}$ & $\mathrm{H}$ & $\mathrm{H}$ \\
\hline $\mathrm{FFC}$ & $100 \mu \mathrm{g}$ & $\mathrm{H}$ & $\mathrm{H}$ & D & $\mathrm{H}$ & $\mathrm{H}$ \\
\hline DO & $100 \mu \mathrm{g}$ & $\mathrm{H}$ & $\mathrm{H}$ & $\mathrm{H}$ & $\mathrm{H}$ & $\mathrm{H}$ \\
\hline TA & $50 \mu \mathrm{g}$ & $\mathrm{H}$ & $\mathrm{H}$ & $\mathrm{H}$ & $\mathrm{H}$ & $\mathrm{H}$ \\
\hline FFC & $50 \mu \mathrm{g}$ & $\mathrm{H}$ & $\mathrm{H}$ & D & $\mathrm{H}$ & $\mathrm{H}$ \\
\hline DO & $50 \mu \mathrm{g}$ & $\mathrm{H}$ & $\mathrm{H}$ & $\mathrm{H}$ & $\mathrm{H}$ & $\mathrm{H}$ \\
\hline TA & $25 \mu \mathrm{g}$ & $\mathrm{H}$ & $\mathrm{H}$ & $\mathrm{H}$ & $\mathrm{H}$ & $\mathrm{H}$ \\
\hline $\mathrm{FFC}$ & $25 \mu \mathrm{g}$ & $\mathrm{H}$ & $\mathrm{H}$ & D & $\mathrm{H}$ & $\mathrm{H}$ \\
\hline DO & $25 \mu \mathrm{g}$ & $\mathrm{H}$ & $\mathrm{H}$ & $\mathrm{H}$ & $\mathrm{H}$ & $\mathrm{H}$ \\
\hline TA & $12,5 \mu \mathrm{g}$ & D & D & $\mathrm{H}$ & $\mathrm{H}$ & D \\
\hline FFC & $12,5 \mu \mathrm{g}$ & $\mathrm{H}$ & $\mathrm{H}$ & D & $\mathrm{H}$ & $\mathrm{H}$ \\
\hline DO & $12,5 \mu \mathrm{g}$ & $\mathrm{H}$ & $\mathrm{H}$ & $\mathrm{H}$ & $\mathrm{H}$ & $\mathrm{H}$ \\
\hline TA & $6,25 \mu \mathrm{g}$ & D & D & D & D & D \\
\hline FFC & $6,25 \mu \mathrm{g}$ & $\mathrm{H}$ & $\mathrm{H}$ & D & $\mathrm{H}$ & $\mathrm{H}$ \\
\hline DO & $6,25 \mu \mathrm{g}$ & $\mathrm{H}$ & $\mathrm{H}$ & $\mathrm{H}$ & $\mathrm{H}$ & $\mathrm{H}$ \\
\hline TA & $3,125 \mu \mathrm{g}$ & D & D & D & D & D \\
\hline $\mathrm{FFC}$ & $3,125 \mu \mathrm{g}$ & D & $\mathrm{H}$ & D & $\mathrm{H}$ & $\mathrm{H}$ \\
\hline DO & $3,125 \mu \mathrm{g}$ & $\mathrm{H}$ & $\mathrm{H}$ & $\mathrm{H}$ & $\mathrm{H}$ & $\mathrm{H}$ \\
\hline Kontrol & $0 \mu \mathrm{g}$ & D & D & D & D & D \\
\hline
\end{tabular}

Tablo 7. Farklı antibiyotiklerin zon çapı standartları.

Table 7. Zone diameter standards of different antibiotics.

\begin{tabular}{lcccc}
\hline \multirow{2}{*}{ Antimikrobiyal ajanlar } & \multicolumn{4}{c}{ Ölçülen inhibisyon zon çapı (mm) } \\
\cline { 2 - 5 } & $\leq 13$ & OH & H & Literatür \\
\hline AM-10 $\mu \mathrm{g}$ & $\leq 12$ & $13-16$ & $\geq 17$ & CLSI, 2014 \\
CN-10 $\mu \mathrm{g}$ & $\leq 10$ & $11-13$ & $\geq 15$ & CLSI, 2014 \\
DO-30 $\mu \mathrm{g}$ & $\leq 16$ & $17-20$ & $\geq 21$ & CLSI, 2013 \\
ENR-5 $\mu \mathrm{g}$ & $\leq 14$ & $15-18$ & $\geq 19$ & CLSI, 2014 \\
FFC-30 $\mu \mathrm{g}$ & $\leq 14$ & $15-18$ & $\geq 19$ & CLSI, 2014 \\
T-30 $\mu \mathrm{g}$ & $\leq 12$ & $13-16$ & $\geq 17$ & CLSI, 2014 \\
SMZ-100 $\mu \mathrm{g}$ & $\leq 10$ & $11-15$ & $\geq 16$ & CLSI, 2014 \\
SXT-25 $\mu \mathrm{g}$ & $\leq 16$ \\
\hline AM: Ampisilin, CN: Gentamisin, DO: Doksisiklin, ENR: Enrofloksasin, FFC: Florfenikol, T: Oksitetrasiklin, SMZ: \\
Sulfamethoksazol, SXT: Trimethoprim/Sulfamethaksazol, D: Dirençli, OH: Orta Hassas, H: Hassas. \\
AM: Ampisiline, CN: Gentamicin, DO: Doxycycline, ENR: Enrofloxacin, FFC: Florfenicol, T: Oxytetracycline, \\
SMZ: Sulphamethxazole, SXT: Trimethoprim/Sulfamethoxazole, D: Resistant, OH: Intermediate, H: Sensitive.
\end{tabular}

Agar Disk Difüzyon Testi: Test mikroorganizmalarına karşı sekiz farklı antibiyotiğin disk difüzyon testi kullanılarak yapılan antimikrobiyal duyarlılık testi sonucu ölçülen zon çaplarına ait değerler Tablo 7'de verilen standart zon çap1 değerleri ile karşılaştırılarak mikroorganizmaların antimikrobiyal hassasiyetleri belirlendi. Çalıșmada kullanılan bakterilerden $P$. fluorescens' in gentamisin ve doksisiklin hariç çalışmada kullanılan diğer antimikrobiyallerin hepsine dirençli olduğu, A. hydrophila, E. coli, V. anguillarum ve $Y$. ruckeri'nin ise ampisilin hariç diğer antibiyotiklere karşı duyarlı olduğu tespit edildi. Test mikroorganizmalarının sekiz antibiyotiğe karşı hassasiyet değerleri Tablo 8'da verildi.

Tablo 8. Test mikroorganizmalarına karşı sekiz antibiyotiğin antimikrobiyal hassasiyeti.

Table 8. Antimicrobial susceptibility of eight antibiotics against test microorganisms.

\begin{tabular}{lccccc}
\hline \multirow{2}{*}{ Antibitotk Diskler } & \multicolumn{5}{c}{ Bakteri izolatları } \\
\cline { 2 - 6 } & E. coli & A. hydrophila & $\boldsymbol{P}$-73 & V-976 & Y. ruckeri \\
\hline AM $(10 \mu \mathrm{g})$ & D & D & D & D & D \\
CN $(10 \mu \mathrm{g})$ & H & H & H & H & H \\
DO $(30 \mu \mathrm{g})$ & H & H & H & H & H \\
ENR $(5 \mu \mathrm{g})$ & H & H & D & H & H \\
FFC $(30 \mu \mathrm{g})$ & H & H & D & H & H \\
OTC $(30 \mu \mathrm{g})$ & H & H & D & H & H \\
SMZ $(100 \mu \mathrm{g})$ & H & H & D & H & H \\
STX $(25 \mu \mathrm{g})$ & H & H & D & H & H \\
\hline AM: Ampisilin, CN. Gentamicin, DO- Doksisiklin, ENR: Enrofloksasin, FFC: Florfenikol, T: Oksitetrasiklin, SMZ:
\end{tabular}

Sulfamethoksazol, SXT: Trimethoprim+Sulfamethaksazol, D: Dirençli, $\mathrm{OH}$ : Orta Hassas, H: Hassas.

AM: Ampicilline, CN: Gentamicin, DO: Doxycycline, ENR: Enrofloxacin, FFC: Florfenicol, T: Oxytetracycline, AMZ: Sulphamethxazole, SXT: Trimethoprim/Sulfamethoxazole, D: Resistant, OH: Intermediate, H: Sensitive 


\section{Minimal Inhibe Edici Konsantrasyon (MiK)}

Belirlenmesi: $\mathrm{Bu}$ çalışmada MHB'da iki katlı dilüsyon yöntemi ile hazırlanan tannik asitin (0,2 ve 0,3 gr stok) farklı konsantrasyonlarına karşı beş farklı bakteri izolatlarının MİK değerine araştırıldı. A. hydrophila'nın minimal inhibe edici konsantrasyonu (MİK) 187,5 $\mu \mathrm{g} / \mathrm{ml}$ konsantrasyonda üremenin meydana gelmesine karşın 250 $\mu \mathrm{g} / \mathrm{ml}$ konsantrasyona sahip tüplerde üremenin olmadığ gözlenmiştir. Tannik asitin ilave edilmiş MHB tüplerinde A. hydrophila'nı üremediği ilk tüp olarak değerlendirildiğinde $250 \mu \mathrm{g} / \mathrm{ml}$ MİK değeri olarak kabul edilmiştir. Test sonucu yapılan değerlendirmede $E$. coli ve $Y$. ruckeri edilmiş farklı konsantrasyonlarda tannik asit için MİK değerinin sırasıyla, 187,5 $\mu \mathrm{g} / \mathrm{ml}$ ve $125 \mu \mathrm{g} / \mathrm{ml}$ konsantrasyonlara sahip tüpte olduğu tespit edildi. Tannik asitin MíK değeri $P$. fluorescens için $31,25 \mu \mathrm{g} / \mathrm{ml}$ ve $V$. anguillarum için ise $375 \mu \mathrm{g} / \mathrm{ml}$ konsantrasyona sahip tüpte olarak tespit edildi (Tablo 9).

Tablo 9. Beş farklı bakteri izolatlarına karşı tannik asitin oluşturduğu MİK değerleri.

Table 9. MIC values of tannic acid against five different bacterial isolates.

\begin{tabular}{llccccc}
\hline Silvafeed & \multirow{2}{*}{ Konsantrasyon } & \multicolumn{5}{c}{ Bakteri izolatlart } \\
\cline { 3 - 7 } & & E. coli & A. hydrophila & P-73 & V-976 & Y. Ruckeri \\
\hline TA & $3000 \mu \mathrm{g}$ & - & - & - & - & - \\
TA & $1500 \mu \mathrm{g}$ & - & - & - & - & - \\
TA & $1000 \mu \mathrm{g}$ & - & - & - & - & - \\
TA & $750 \mu \mathrm{g}$ & - & - & - & - & - \\
TA & $500 \mu \mathrm{g}$ & - & - & - & - & - \\
TA & $375 \mu \mathrm{g}$ & - & - & - & - & - \\
TA & $250 \mu \mathrm{g}$ & - & - & - & + & - \\
TA & $187,5 \mu \mathrm{g}$ & - & + & - & + & - \\
TA & $125 \mu \mathrm{g}$ & + & + & - & + & - \\
TA & $93,75 \mu \mathrm{g}$ & + & + & - & + & + \\
TA & $62,5 \mu \mathrm{g}$ & + & + & - & + & + \\
TA & $46,875 \mu \mathrm{g}$ & + & + & - & + & + \\
TA & $31,25 \mu \mathrm{g}$ & + & + & - & + & + \\
TA & $23,44 \mu \mathrm{g}$ & + & + & + & + & + \\
TA & $15,625 \mu \mathrm{g}$ & + & + & + & + & + \\
TA & Kontrol & + & + & + & + & + \\
\hline +: Bakteriyel üremenin var, + : There is bacterial growth, $-:$ Bakteriyel üremenin yok, $-:$ There is no bacterial growth. &
\end{tabular}

Beş farklı bakteri türü izolatlarına karşı florfenikolün MHB'da iki katlı seyreltilerek hazırlanan dilüsyonları ile yapılan test sonucunda edilen MIK değerleri belirlenmiştir. Farklı konsantrasyonlarda florfenikol içeren tüplere $E$. coli ilave edildiğinde MIK değerinin $25 \mu \mathrm{g} / \mathrm{ml}$ olduğu tespit edildi. A. hydrophila ilave edilen tüplerden florfenikol'ün MİK değeri $12,5 \mu \mathrm{g} / \mathrm{ml}$ yoğunluğundaki tüpte meydan geldiği tespit edildi. Forfenikolün farklı konsantrasyonlarındaki dilüsyonlarına $P$. fluorescens izolatı ilave edilmiş tüplerin hepsinde üreme meydana geldiği için MIK değeri tespit edilemedi. Florfenikolün farklı konsantrasyonlarındaki tüplerine $V$. anguillarum ilave edildiğinde üremenin olmadığı 12,5 $\mu \mathrm{g} / \mathrm{ml}$ yoğunluğundaki ilk tüp MİK değeri olarak belirlendi. Farklı konsantrasyondaki florfenikol içeren tüplere $Y$. ruckeri ilave edildiğinde $50 \mu \mathrm{g} / \mathrm{ml}$ içeren üreme olmadığı ilk tüp MİK değeri olarak tespit edildi. Beş farklı bakteri izolatına karşı florfenikolün iki katlı dilüsyonlarının oluşturduğu MIK değerlerine ait veriler Tablo 10'de sunulmuştur.
Tablo 10. Beş farklı bakteri izolatlarına karşı florfenikolün MİK değerleri.

Table 10. MIC values of florfenicol against five different bacterial isolates.

\begin{tabular}{llccccc}
\hline Kimyasal & \multirow{2}{*}{ Konsantrasyon } & \multicolumn{5}{c}{ Bakteri izolatları } \\
\cline { 2 - 7 } & & E. coli & A. hydrophila & P-73 & -976 & Y. ruckeri \\
\hline FFC & $100 \mu \mathrm{g}$ & - & - & + & - & - \\
FFC & $50 \mu \mathrm{g}$ & - & - & + & - & - \\
FFC & $25 \mu \mathrm{g}$ & - & - & + & - & + \\
FFC & $12,5 \mu \mathrm{g}$ & + & - & + & - & + \\
FFC & $6,25 \mu \mathrm{g}$ & + & + & + & + & + \\
FFC & $3,125 \mu \mathrm{g}$ & + & + & + & + & + \\
FFC & $1,56 \mu \mathrm{g}$ & + & + & + & + & + \\
FFC & $0,78 \mu \mathrm{g}$ & + & + & + & + & + \\
FFC & $0,39 \mu \mathrm{g}$ & + & + & + & + & + \\
Kontrol & $0,00 \mu \mathrm{g}$ & + & + & + & + & + \\
\hline FFC: Florfenikol, $+:$ Bakteriyel üreme var, $-:$ Bakteriyel üreme yok. FFC: Florfenicol, +: There is bacterial growth, -: \\
\multicolumn{2}{l}{ No bacterial grow }
\end{tabular}

\section{SONUÇ VE TARTIŞMA}

Ülkemizde kültürü yapılan gökkuşağı alabalık yavru ve porsiyonluk boydaki balıklarda özellikle su sıcaklığına bağlı olarak ortaya çıkan ve toplu ölümlere neden olan Gram negatif bakteriyel balık patojenlerinden; A. hydrophila, $P$. fluorescens, $Y$. ruckeri ve $V$. anguillarum tarafindan meydana getirilen enfeksiyonların tedavisinde antibiyogram test sonuçlarına göre farklı antibiyotikler kullanılmaktadır (Cagirgan \& Tanrikul, 1998;Balta vd., 2010;2016; Balta \& Dengiz Balta, 2016; 2017; 2019; Balta, 2020). Kültür balıkçılığında, hastalıkların tedavisinde gelişi güzel antibiyotik kullanımı bazı problemleri beraberinde getirmektedir. Antibiyotikler, uygun süre ve dozda kullanılmadığında bakterilerde bu antibiyotiklere karşı geçici (biyokimyasal) ve kalıcı (genetik) direnç şekillenmektedir. Bu durum daha sonra ortaya çıkan aynı enfeksiyonların tedavisinde başarısızlığa ve rezidü problemlerine neden olmaktadır (Cagirgan \& Tanrikul, 1998; Balta, 1999; Balta \& Çağırgan, 2007; Balta \& Çağırgan, 2010;Balta, 2016; Balta \& Dengiz Balta, 2019; Balta \& Y1lmaz, 2019; Onuk vd., 2015; 2017; Duman vd., 2017; Dinçtürk \& Tanrıkul, 2021). Tannik asit bitkilerin gövde, yaprak vs. gibi farklı bölgelerinden elde edilen polifenolik yapıda suda eriyen bir bileşiktir. Tanenlerin, antimikrobiyal, antienflamatuar, antiviral, antioksidan ve antiparazitik aktiviteler gibi önemli biyolojik özelliklere sahip olduğu bildirilmektedir(Aydın \& Üstün, 2007; CiprianoSalazara vd., 2018; Kaczmarek, 2020). Bitkilerden elde edilen tannik asit, doğal bir madde olması nedeni ile bakterilerin meydana getirdiği hastalıkların tedavisinde kullanımı bir ayrıcalıktır. Bu çalışmada, tannik asittin bakteriyel balık hastalıkların hangisinin tedavisinde etkili olduğu belirlenmesi amaçlanmıştır. Tannik asittin balık patojenlerinin tedavisinde kullanılması, balıketinde kemoterapotik maddelerin kalıntı problemlerine neden olmaması, çevre kirliliği ve insan sağlığına olumlu etkilerinin yanı sıra yurt dışına balık ihracatını da kolaylaştıracaktır. Tannik asit, balık etinde rastlanılacak antibiyotik kalıntıları sonucu insanlarda oluşabilecek 
kanserojenik ve mutajenik muhtemel etkilerin önüne geçilebileceği düşünülmektedir.

$\mathrm{Bu}$ araştırmada, Karadeniz Bölgesindeki faaliyet gösteren balık çiftliklerindeki hasta balıkların iç organlarından izole edilen Gram negatif; A. hydrophila, $P$. fluorescens, $Y$. ruckeri ve $V$. anguillarum'a karşı, tannik asitin farklı düzeyde antimikrobiyel etkinliğe sahip olduğu tespit edilmiştir. Tannik asitin balık patojenleri üzerine etkilerinin araştırıldı $\mathrm{g} 1$ çalışmalar oldukça sınırlıdır. $\mathrm{Bu}$ çalışmalarda tannik asitin antioksidan aktivitesi, bağırsak mikroflorası ve bağırsak hareketleri üzerine etkileri çalışılmıştır (Sell vd., 1985; Yılmaz \& Romeo, 2004; Schiavone vd., 2008). Tannik asit'in yem katk1 maddesi olarak lezzetlendirici özelliği sayesinde, kanatlllarda yem alımını artırdığı ve yem stresini düşürdüğü bildirilmiştir (Zaccarato vd., 2006; Schiavone vd., 2008). Rekabetçi dışlama mekanizması sayesinde mikroflora tercihini değiştirerek mikroflorayı dengelediği (Schiavone vd., 2008), patojen bakterilerin artmasını ve toksin oluşumunu baskıladığı için hayvan refahını artırdığı, üreme performansını artırdığı, antibiyotik kullanımını azalttığı, balık ölümlerini azalttığı ve büyüme performansını iyileştirici etkinliğe sahip olduğu bildirmiş̧ir (Zaccarato vd., 2006; Zoccarato vd., 2008).

Kültür balıklarının, bitkilerden elde edilen chaga mantarı (Inonotus obliquus) ekstraktı ile beslenmesinin iştah artışına bağlı kilo artışı sağladığı, $V$. harveyi ile enfekte edilen balıklarda beyaz kan hücresi ve kırmızı kan hücresi seviyelerinin, hemoglobin, hematokrit, lenfositlerin ve monositlerin önemli ölçüde $\operatorname{artırdığ~}$ bildirilmiştir (Harikrishnan vd., 2012). A. hydrophila'ya karşı aşı geliştirilmesi amacıyla yapılan bir çalışmada, yavru sazan balıklarına kutsal fesleğen (Ocimum sanctum) bitki ekstraktının düşük dozda $(10 \mathrm{ppm})$ verildiğinde kontrol ve diğer deney gruplarına (20 ve $30 \mathrm{ppm}$ ) göre maksimum antikor yanıtı sağladığı ve daha fazla fagositik aktivite gösterdiğinin tespit edildiği rapor edilmiștir (Pavaraj vd., 2011). Üç farklı (Crataegi fructus (Cf), Artemisia capillaries ve Cnidium officinale) tıbbı bitkinin özütleri ve karışımlarının, kırmızı çipura (Mercan) larvalarında büyüme ve $V$. anguillarum'a karşı etkilerinin araştırıldığı bir araştırmada, bu bitki ekstratları ile beslenen rotiferlerde Vibrio sayısının azaldığı tespit edilmiştir. Cf özütü bulunduran içerikler ile beslenen rotiferlerin diğer gruplara oranla istatistik olarak boylarının daha fazla büyüdüğü tespit edilmiştir. Aynı çalışmada $\mathrm{Cf}$ ve bu bitki karışımlarının methanol özütleri, Aeromonas, Edwasiella, Photobacterium, Pseudomonas ve Vibrio sp. cinsleri dahil, yedi bulaşıcı bakteri izolatının çoğalmasını engellediği bildirilmiştir. Bitki özü karışımı ile beslenmiş rotiferlerin beslendiği larvaların hayatta kalma oranı $V$. anguillarum ile yapılan çelinç testinde kontrol grubuna göre oldukça yüksek bulunmuştur. Bu sonuçlar, bitki özü ile beslenen rotiferlerin, çipura larvalarında büyüme ve $V$. anguillarum'a karşı direnci artırmak için faydalı olduğunu ve hastalığa dirençli yavrularının sürdürülebilir üretimi için yeni bir teknoloji sağladığını ortaya koymuşlardır (Takaoka vd., 2011). Yapılan bir başka çalışmada $A$. hydrophila, A. salmonicida, A. bestiarum, A. sobria, Listonella anguillarum, L. garviae, $P$. fluorescens, $P$. anguilliseptica, $Y$. ruckeri ve $V$. salmoninarum gibi önemli balık patojenlerine karşı Silvafeed TSP'nin 6 farklı konsanrasyonunun $(\% 0,05,0,01,0,02,0,04,0,08$ ve 0,1$)$ Kirby-Bauer disk difüzyon yöntemi kullanılarak antimikrobiyal etkinliğinin test edildiği bildirilmiştir (Tanrıkul \& Dinçtürk, 2017). Silvafeed TSP'nin tüm konsantrasyonlarının $L$. anguillarum ve $Y$. ruckeri'ye karşı hassas olmasına karşın $L$. garviae ve $V$. salmoninarum'a dirençli olduğu rapor edilmiştir. Aeromonas türlerinin (A. bestiarum, $\% 0,05$ hariç) hassas olduğu, $P$. fluorescens ve $P$. anguilliseptica ilk iki konsantrasyonda $(\% 0,05$ ve 0,01$)$ orta hassasiyette olmasına karşın diğer dört konsantrasyonlarda ise duyarlı olduğu tespit edilmiştir (Tanrıkul \& Dinçtürk, 2017). Fitokimyasalların etkileri üzerine yapılan bir çalışmada oxytetracycline ve enrofloxacin antibiyotiklerinin $Y$. ruckeri'ye dirençli olduğunu bildirmesine rağmen, aynı çalışmada moringa (Moringa oleifera) ve üvez (Sorbus domestica) bitki ekstraktlarının sıvı ortamda (TSB) yapılan ölçümlerde, bakteri üremesini \%40-50 oranında engellemesine karșın katı ortam (MHA) üzerindeki etkilerinin ise daha az olduğu rapor edilmiştir (Önalan \& Çevik, 2020). Bu çalışmanın sonuçları ile Tanrıkul ve Dinçtürk (2017)'ün tanik asit üzerine yaptı̆̆ı çalışmalar ile Önalan ve Çevik (2020)'in fitokimyasalların etkileri üzerine yaptığı çalışmaları bulguları ile paralellik göstermiştir.

$\mathrm{Bu}$ çalışma sonunda, bakteriyel balık patojenlerinin tedavisinde Gram negatif bakteriler karşı Silvafeed TSP etkili olabileceği ve hastalıkların tedavisinden çok yem katkısı olarak hastalık çıkmadan önce koruyucu amaçla yemlere katılmasının faydalı olacağı düşünülmüştür.

\section{ÖNERILLER}

$\mathrm{Bu}$ çalı̧̧mada, Silvafeed TSP'nin balıklarda hastalık yapan, özellikle Gram negatif (A. hydrophila, $P$. fluorescens, $V$. anguillarum ve $Y$. ruckeri) bakterilere karşı etkili olduğu için su ürünleri yetiştiriciliğinde, hastalık önleyici yem katkı maddesi olarak kullanılabileceği kanısına varılmıştır. Balıklarda özellikle antibiyotiklere karşı direnç şekillenmiş tedavi edilemeyen (P. fluorescens $v s)$ etkenlere karşı tannik asitin etkili olabildiği fakat daha fazla izolatın antibakteriyel etkinliğini belirlemek için yeni çalışmaların yapılması gerektiği düşünülmektedir. $\mathrm{Bu}$ çalışmada florfenikole karşı disk difüzyon yönteminde 
dirençli olan $P$. fluorescens bakteri izolatına karşı tannik asitin disk difüzyon yönteminde $125 \mu \mathrm{g} / \mathrm{ml}$ ve üzeri konsantrasyonların etkili olduğu, aynı bakteri için florfenikol'ün ise $200 \mu \mathrm{g} / \mathrm{ml}$ duyarlı olmasına karşın 100 $\mu \mathrm{g} / \mathrm{ml}$ dirençli olduğu belirlenemiştir. Tannik asit'in MİK değeri $31,25 \mu \mathrm{g} / \mathrm{ml}$ olarak tespit edilmesine karşı florfenikol'ün hazırlanan en yüksek konsantrasyonda(100 $\mu \mathrm{g} / \mathrm{ml}$ ) bile MIKK değeri tespit edilememiştir. Bu nedenle antibiyotiğe dirençli $P$. fluorescens karşı tannik asit daha ayrıntılı çalışılmaların yapılması gerekmektedir. Ayrıca, tannik asidin yem katkı maddesi olarak farklı konsantrasyonlarda balık yemelerine karıştırılıp yedirme denemelerinin yapılarak büyüme performansları ve kan hücreleri üzerine etkilerinin çalışılması gerektiği düşünülmektedir. Balıklarda kullanılan antibiyotiklerin, akuatik ortamdaki bakterilerde dirençli suşların oluşmasına ve balıketinde kalıntı problemlerine neden olabileceği için bitkisel kaynaklı doğal bir madde olması nedeni ile tannik asit içerikli yem katkı maddelerin faydalı olacağı için balık yetiştiriciliğinde kullanılması tavsiye edilebilir. $\mathrm{Bu}$ nedenle bir sonraki çalışmada silvafeed TSP'nin balık yedirme denemelerinin yapılacağı yeni bir çalışmanın yapılması planlanmaktadır.

\section{TEŞEKKÜR}

$\mathrm{Bu}$ yüksek lisans tezi çalışması Recep Tayip Erdoğan Üniversitesi, Bilimsel Araştırma Projeleri Başkanlığı tarafından FYL-2019-994 nolu proje ile desteklenmiştir.

\section{KAYNAKLAR}

Aydın, S.A. \& Üstün, F. (2007). Tanenler 1. Kimyasal yapıları, farmakolojik etkileri, analiz yöntemleri. İstanbul Üniversitesi Veteriner Fakakültesi Dergisi, 33(1), 21-31.

Bae, H.D., McAllister, T.A., Yanke, L.J., Cheng, K.J. \& Muir, A.D. (1993). Effects of condensed tannins on endoglucanase activity and filter paper digestion by Fibrobacter succinogenes S85. Applied and Environmental Microbiology, 59, 2132-2138. DOI: 10.1128/aem.59.7.2132-2138.1993

Balta, F. \& Çağırgan, H. (2007). Levrek'lerde (Dicentrarchus labrax L., 1758) sağaltım sonrası oksitetrasiklinin kas ve derideki rezidüsünün belirlenmesi. E.U. Journal of Fisheries \& Aquatic Sciences, 24(1), 173-178.

Balta, F. \& Çă̆ırgan, H. (2010). Oxytetracycline residues in cultured gilthead sea bream (Sparus aurata L. 1758) tissues. African Journal of Biotechnology, 9(42), 71927196.

Balta, F. \& Dengiz Balta Z. (2019). The isolation of Lactococcus garvieae from eyes of diseased rainbow trout (Oncorhynchus mykiss) with exopthalmia. Journal of Anatolian Environmental and Animal Sciences, 4(1), 27-33. DOI: $10.35229 /$ jaes.527258

Balta, F. \& Dengiz Balta, Z. (2016). Deniz suyuna nakledilen gökkuşağı alabalığı (Oncorhynchus mykiss) yavrularında görülen vibrio enfeksiyonu ve tedavisi Anadolu Çevre ve Hayvancılık Bilimleri Dergisi, 1(1), 14-20.

Balta, F. \& Dengiz Balta, Z. (2017). Doğu Karadeniz'de yetiştiriciliği yapılan gökkuşağı alabalıkları (Oncorhynchus mykiss)'ndan izole edilen Vibrio anguillarum suşlarının serotiplendirilmesi, genetik karakterizasyonu ve antimikrobiyal duyarlılığının belirlenmesi. Ankara Üniversitesi Veteriner Fakültesi Dergisi, 64, 321-328.

Balta, F. \& Dengiz Balta, Z. (2019). Preparation of O-antigen from Yersinia ruckeri serotype $\mathrm{O} 1$ and use in the slide agglutination test. Anatolian Env. and Anim. Sciences, 4(3), 480-483. DOI: 10.35229/jaes.645416

Balta, F. \& Yılmaz, H. (2019). Kültür levreklerinde (Dicentrarchus labrax) Vibrio parahaemolyticus enfeksiyonu. Journal of Anatolian Environmental and Animal Sciences, 4(2), 104-110. DOI: $10.35229 /$ jaes.544439

Balta, F. (1999).Levrek (Dicentrarchus labrax L., 1758) balıklarında sağaltım sonrası oksitetrasiklin rezidüsünün belirlenmesi. Doktora Tezi, Ege Üniversitesi Fen Bilimleri Enstitüsü, İzmir, 93s.

Balta, F. (2016). Phenotypic, serotypic and genetic characterization and antimicrobial susceptibility determination of Vibrio anguillarum, isolatedf cultured sea bass (Dicentrarchus labrax L., 1758) in the Southeast Black Sea, Turkey. Fresenius Environmental Bulletin, 25(10), 4393-4400.

Balta, F. (2020). Firtına Deresindeki gökkuşağı alabalık çiftliklerinde izole edilen Aeromonas spp. izolatlarının antimikrobiyel hassasiyetin belirlenmesi. Anadolu Çevre ve Hayvancllık Bilimleri Dergisi, 5(3), 397-407. DOI: 10.35229/jaes.785447

Balta, F., Dengiz Balta, Z., Ozgumus, O.B. \& Çă̆ırgan, H. (2016). Doğu Karadeniz Bölgesi'ndeki gökkuşağ 1 alabalığı (Oncorhynchus mykiss) çiftliklerinde Yersinia ruckeri'nin portörlük yönünden tetkiki ve antimikrobiyal direncin tespiti. Anadolu Çevre ve Hayvancilık Bilimleri Dergisi, 3(1), 72-76.

Balta, F., Sandalli, C., Kayis, S. \& Ozgumus, O.B. (2010). Molecular analysis of antimicrobial resistance in Yersinia ruckeri strains isolated from rainbow trout (Oncorhynchus mykiss) grown in commercial fish farms in Turkey. Bulletin of the European Association of Fish Pathologists, 30(6), 211-219.

Beşe, M. (1989). Mikrobiyolojide Kullanılan Antibiyotik Duyarlılık ve Deneme Yöntemleri. İstanbul Üniversitesi, Veteriner Fakültesi Yayınları, İstanbul, $133 \mathrm{~s}$.

Brooker, J.D., O'Donovan, L.A., Skene, I., Clarke, K., Blackall, L. \& Muslera, P. (1994). Streptococcus caprinus sp. nov., a tannin-resistant ruminal bacterium from feral goats. Letters in Applied Microbiology, 18, 313-318. DOI: 10.1111/j.1472-765X.1994.tb00877.x

Cagirgan, H. \& Tanrikul, T.T. (1998). Testing the effectiveness of a Yersinia vaccine in infected and chemically treated juvenile rainbow trout (Oncorhynchus mykiss). Journal of Applied Ichthyology, 14, 239-243.

Cipriano Salazara, M., Rojas Hernándeza, S., Olivares Péreza, J., Jiménez Guillénb, R., Cruz Lagunasc, B., Camacho Díaza, L.M. \& Ugbogud, A E.(2018). Antibacterial activities of tannic acid against isolated ruminal bacteria from sheep. Microbial Pathogenesis, 117, 255-258. DOI: 10.1016/j.micpath.2018.01.045

CLSI. (20013). Performance Standards for Antimicrobial Susceptibility Testing; Twenty-Third Informational 
Supplement. CLSI document M100-S23. Vol. 33, No.1, Wayne, PA.

CLSI. (2014). Performance standards for antimicrobial susceptibility testing. Twenty-Fourth Informational Supplement. Clinical Laboratory Standards Institute, Wayne, USA, M100-S24, 230.

Dinçtürk, E. \& Tanrıkul, T.T. (2021). Yersinia ruckeri and Pseudomonas fluorescens co-infection in rainbow trout (Oncorhynchus mykiss Walbaum, 1792). Aquaculture Research, 52(10), 4858-4866. DOI: 10.1111/are.15320

Duman, M., Altun, S., Cengiz, M., Saticioglu, I.B., Buyukekiz, A.G. \& Sahinturk, P. (2017). Genotyping and antimicrobial resistance genes of Yersinia ruckeri isolates from rainbow trout farms. Diseases of Aquatic Organisms, 125, 31-44. DOI: 10.3354/dao03132

EL-Hefny, M., Ashmawy, N.A., Salem, M.Z.M. \& Salem, A.Z.M. (2017). Antibacterial activities of the phytochemicals-characterized extracts of Callistemon viminalis, Eucalyptus camaldulensis and Conyza dioscoridis against the growth of some phytopathogenic bacteria. Microbial Pathogenesis, 113, 348-356. DOI: 10.1016/j.micpath.2017.11.004

Goel, G., Puniya, A.K. \& Singh, K. (2005). Tannic acid resistance in ruminal streptococcal isolates. Journal of Basic Microbiology, 45, 243-245. DOI: 10.1002/jobm.200410517

Harikrishnan, R., Balasundaram, C. \& Heo, M.S. (2012). Effect of Inonotus obliquus enriched diet on hematology, immune response, and disease protection in kelp grouper, Epinephelus bruneus against Vibrio harveyi. Aquaculture, 344-349, 48-53. DOI: 10.1016/j.aquaculture.2012.03.010

http-1. (2021). Silvafeed TSP. Silvateam. Products and services, plant based extracts. https://www.silvateam.com

Kacar, Z.Z. \& Balta, F. (2017). Multi locus sequence analysis (MLSA)-based identification of Pseudomonas spp. isolated from rainbow trout (Onchorhynchus mykiss) in the Eastern Black Sea Region of Turkey using. Fresenius Environmental Bulletin, 26(12), 7506-7512.

Kaczmarek, B. (2020). Tannic acid with antiviral and antibacterial activity as a promising component of biomaterials-a minireview. Materials, 13, 3224, DOI: 10.3390/ma13143224

NCLLS. (1993). Performance standards for antimicrobial disk susceptibility tests. Approved standard. NCCLS document M2-A5.Wayne, Pa: National Committee for Clinical Laboratory Standards.

Onuk, E.E., Çaycı, Y.T., Çoban, A.Y., Çiftci, A., Balta, F., Didinen, B.I., Pekmezci, G.Z., Altun, S., Ünlü, M.S. ve Deveci, A. (2015). Türkiye'de su kaynaklı Aeromonas izolatlarında saptanan ilk QnrS gen Pozitifliği. Mikrobiyoloji Bülteni, 49(1), 114-123.

Onuk, E.E., Çaycı, Y.T., Çoban, A.Y., Çiftci, A., Balta, F., Didinen, B.I. ve Altun, S. (2017). Balık ve yetiştirme suyu kökenli Aeromonas izolatlarının antimikrobial duyarlılıklarının saptanması. Ankara Üniv. Vet. Fa.k Derg., 64(1), 69-73.

Önalan, Ş. \& Çevik, M. (2020). Investigation of the effects of some phytochemicals on Yersinia ruckeri and antimicrobial resistance. Brazilian Journal of Biology, 80(4), 934-942. DOI: 10.1590/1519-6984.234969

Pavaraj, M., Balasubramanian, V., Baskaran, S. \& Ramasamy, P. (2011). Development of immunity by extract of medicinal plant Ocimum sanctum on common carp Cyprinus carpio (L.). Research Journal of Immunology, 4(1), 12-18. DOI: 10.3923/rji.2011.12.18
Pérez-Fonseca, A., Alcala-Canto, Y., Salem, A.Z.M. \& Alberti-Navarro, A.B. (2016). Anticoccidial efficacy of naringenin and a grapefruit peel extract in growing lambs naturally-infected with Eimeria spp. Veterinary Parasitology, 232, 58-65. DOI: 10.1016/j.vetpar.2016.11.009

Salem, A.Z.M., Robinson, P.H., Lopez, S., Gohar, Y.M., Rojo, R. \& Tinoco, J.L. (2010). Sensitivity of sheep intestinal lactic acid bacteria to secondary compounds extracted from Acacia saligna leaves. Animal Feed Science and Technology, 161, 85-93. DOI: 10.1016/j.anifeedsci.2010.08.003

Schiavone, A., Gua, K., Tassone, S., Gasco, Hernandez, E., Denti, R. \& Zoccarato, I. (2008). Effects of a natural extract of chestnut wood on digestibility, performance traits, and nitrogen balance of broiler chicks. Poultry Science, 87(3), 521-527. DOI: 10.3382/ps.2007-00113

Sell, D.R., Reed, W.M., Chrisman, C.L. \& Rogler, J.C. (1985). Mucin excretion and morphology of the intestinal tract as influenced by sorgunm tannins. Nutrition Raports International, 31, 1369-1374.

Spencer, C.M., Cal, Y., Martin, R., Gaffney, S.H., Goulding, P.N., Magnolato, D., Lilley, T.H. \& Haslam, E. (1988). Polyphenol complexation: some thoughts and observations. Phytochemistry, 27, 2397-2409. DOI: 10.1016/0031-9422(88)87004-3

Takaoka, O., Ji, S.C., Ishimaru, K., Lee, S.W., Jeong, G.S., Ito, J., Biswas, A. \& Takii, K. (2011). Effect of rotifer enrichment with herbal extracts on growth and resistance of red sea bream, Pagrus majör (Temminck \& Schlegel) larvae against Vibrio anguillarum. Aquaculture Research, 42, 1824-1829. DOI: 10.1111/j.1365-2109.2010.02783.x

Tanrikul, T.T. \& Dincturk, E. (2017). Antibacterial susceptibility of hydrolysable tannins (Silvafeed TSP) against bacterial fish pathogens. Aquaculture Europe 2017, October 17-20, Dubrovnik, Croatia.

Yılmaz, Y. \& Romeo, T.T. (2004). Major flavomolds in grapeseeds and skins: antioxidant capacity of catechin, epicatechin, and gallic acid. Journal of Agricultural and Food Chemistry, 52(2), 255-260. DOI: 10.1021/jf030117h

Zoccarato, I., Gasco, L., Schiavone, A., Guo, K., Barge, P., Rotolo, L., Savarino, G. \& Masoero, G. (2008). Effect of extract of chestnut wood inclusion (ENC) in normal and low protein amino acid supplemented diets on heavy broiler rabbits. In Proceedings of the 9th world rabbit congress (pp. 873-877), 10-13 June 2008, Verona, Italy.

Zoccarato, I., Schiavone, A., Tassone, S., Gasco, L. \& Malfatto, V. (2006). Study on the utilisation of a natural silvafeed in the nutrition of heavy chickens. XII European Poultry Conference, Verona, Italy 